\title{
THE ORIGINS OF MODERN CROSS-CULTURAL EUROPEAN INTERPRETATIONS OF CHINESE PHILOSOPHY. NEW THOUGHTS ON CHINA IN THE WORK OF G. W. LEIBNIZ ${ }^{1}$
}

\author{
BŘETISLAV HORYNA
}

\begin{abstract}
Leibniz was not the one to discover China, as far as Western culture was concerned. His historical contribution lies in the fact he presented Europe and China as two distinct ways of contemplating the world, as fully comparable and resulting in types of societies at the same high institutional, economic, technological, political and moral level. In this sense he saw China as the "Europe of the Orient" and as such susceptible to investigation by the same tools of natural philosophy which Leibniz knew from the environs of European scholarship. He was the first representative of the classical school of European philosophy to knowingly reject Eurocentrism. Leibniz followed the intentions of learned missionaries in his understanding of the Christian mission as a cultural and civilisational task, a search for mutual agreement and connections, in favour of a reciprocal understanding.

Keywords: Leibniz; Chinese philosophy; Jesuit mission; Chinese civilisation; Chinese scholarship; scientific development; justice; recognition; equality
\end{abstract}

\section{Introduction}

Cultures may be divided into those with the characteristic propensity to preach to others and those which are able to learn from others. The first require a great deal of self-importance, as well as an even larger dose of arrogance, while cultures with the capacity to learn from others need only the mature self-confidence necessary to comprehend their own limitations and shortcomings, and to prevent their foundations from being undermined. The ability to learn, that is to allow other cultures or civilisations to influence one's thinking, may be considered one of the hallmarks of cultural development. If such a standard were to be applied, European or Western culture in general would seem childlike; the history of the Occident is one of cultural arrogance, of a culture that imposed the notion of its superiority

1 This article is part of VEGA project 1/0291/18 Historic-philosophical analysis of environmental
thinking, research on its influences on ethical, legal and political thinking and its social response.
146
DE DEGRUTER 
and sovereignty over all other cultures. Even today the Occident insists on supremacy and to be the deciding voice in intercultural relations, and for the education of others it offers only brute force (economic, political) and powerful (military) methods, applying them thoughtlessly and without hesitation.

Calls for the Occident to learn from others therefore did not happen often. And rightly so, because such sentiments brought these critics outside the established order, where the recognition and understanding of others was suppressed by the pressures of conquest, control and baptism. One voice that could be heard when modern contact began between the European West (here we must include the Tsardom of Russia) and China was that of Gottfried Wilhelm Leibniz (1646-1716), whose work is considered the beginning of a rational interpretation of Chinese philosophy, religion and knowledge generally (e.g. Widmaier, 2006; Merkel, 1952).

Leibniz was not the one to discover China, as far as Western culture was concerned. His historical contribution lies in his presentation of Europe and China as two distinct ways of contemplating the world, both fully comparable and resulting in types of societies at the same high institutional, economic, technological, political and moral level. In this sense he saw China as the "Europe of the Orient" and as such susceptible to investigation using the same tools of natural philosophy with which Leibniz was familiar from European scholarship. The difference lay precisely in his transferring the focal point of knowledge to philosophy. Leibniz was able to read books about China which dealt predominantly with geography and trade, and which also made some comparisons with regards to possible Christianisation (Kircher, 1667), but the subject of philosophy had yet to be touched upon. The history of trans-cultural relations contains people's basic attitudes to the world and to humanity, to Nature and society, to order and hierarchies, to values and wisdom, and to knowledge. In other words, the complex broader contexts which cultures use to create their identity and which the European cultural tradition refers to as philosophy. Leibniz's emphasis on discerning and understanding the similarities and differences in the comparative interpretation of Western ${ }^{2}$ and Eastern philosophy was therefore entirely appropriate, if only because the roots of cross-civilisational strife often dig down into areas of misunderstood and distorted ideals. However, his desire to move beyond a mere hermeneutics of Chinese spiritual systems (Confucianism, Taoism and Buddhism) to the idea of cross-cultural exchange in the areas where one civilisation was ahead of the other (according to Leibniz the Chinese were ahead in practical philosophy, while the Europeans had much to offer China in the speculative sciences), deserves recognition to this day: he was the first representative of the classical school of European philosophy to knowingly reject Eurocentrism. This can be seen in the preface to Novissima Sinica (Latest from China, Leibniz, 1697), published over 320 years ago. To answer whether Leibniz's rejection of Eurocentrism made him the founder of cross-cultural comparative philosophy, one must look no further than his second ground-

2 In Leibniz's time, a paradigmatic shift away from the old Philosophia perennis to the new Philosophia sectaria and eclectica occurred in "Western philosophy". In the $18^{\text {th }}$ century the scientific method of knowledge and the comprehensive scientification of the West had only just begun. 
breaking work on Chinese philosophy, Discours sur la théologie naturelle des Chinois ${ }^{3}$ (DNT) from the year 1716.

\section{The historical context of Leibniz's interpretation of Chinese scholarship}

\section{Christian missions to China}

Seventeenth century China was in the spotlight of the interest of European scholars. Almost a thousand years of mutual awareness between Europe and China had passed, and neither had even attempted a bilateral understanding of the other, nor had there been any cultural or scientific exchange. The stagnation of direct contacts could be seen in parallel developments, and the function and characteristics of the cultural depictions each civilisation had of the other. This suited their needs and requirements: China had proper cultural relations regarding scholarship with the Islamic world, primarily the Arab world, and before the 18th and 19th centuries it had no need to look for outside assistance. In China's view of the world, China was still the centre, the source of culture and morality, the pinnacle being the emperor, and it was surrounded by uncivilised, barbarian nations. In this sense it was not significantly different from the technologically prosperous European West; however, its socio-political framework surpassed that of the West. China was capable of learning from others without feeling cultural humiliation. It was capable of consciously and deliberately assessing, accepting and socially allocating knowledge, ideas and foreign cultural vision in an effective way that avoided triggering a crisis of personal identity.

Europe, however, carried that burden, due to its notion of religious exceptionalism. The West's undeniable cultural deficit, the result of an inflexible religious idealisation of society, was held up thanks to its prejudices and disdain for others. The Europeans held onto these notions well into the enlightened origins of the modern era, legitimising them through the idea that the knowledge contained in old religious (i. e. holy) books and their exegesis entitled them to a better understanding of the truth of the world than any direct eye-witness accounts. This specifically cultural and anthropological aspect of Europeanism contains a significant dose of aggression towards others or even just images of them, placing much more impenetrable walls between the thinking and actions of people than its Chinese antecedent.

Formally, the relationship between Christian culture and other parts of the globe was

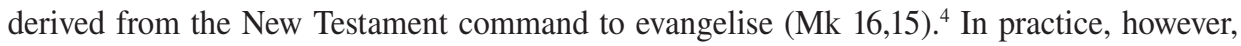
it was based on the Treaty of Tordesillas from 1494, according to which Pope Alexander VI divided the world, with one half belonging to Spain (the West or Occident) and the other half to Portugal (the East or Orient). The era of the forceful and brutal colonisation of previously unknown parts of the globe therefore began at the peak of the European Renaissance and with the support of militant Christianity. The Portuguese, originally the strongest maritime

\footnotetext{
3 Discourse on the Natural Theology of the Chinese (henceforth as DNT).

4 "Go into all the world and preach the gospel to all creation." In Holy Bible, New International Version ${ }^{\circledR}$ 2011. Retrieved from https://www.biblegateway.com/passage/?search=Mark+16\&version $=$ NIV.13/02/2020.
} 
power, managed to make inroads into India in line with the Treaty of Tordesillas, establishing "Portuguese India" (estado da India) with Goa, captured in 1510, as its capital. This aggression continued further into the southeast and, after several failed attempts, reached China in 1557. There Portugal (with the consent of the Chinese government) established its own administrative region on the uninhabited peninsula of Macau (Aomen or Haoching in Chinese), which soon became an incredibly powerful colonial trading town. Macao is especially important in the mutual recognition of Europe and China, since the requirement to evangelise other nations lead to the establishment of the first Christian Jesuit mission in China.

This was not China's first encounter with Christianity. It had had quite a broad experience of the religion throughout its history, due to the role played by the Nestorian and Chaldean churches both during Mongol rule over China and with the establishment of the ruling Chinese dynasty of Ming (1368). However, the founder of the Christian mission to China and its main and most important representative was Italian Jesuit Matteo Ricci (1552-1610; his Chinese name was Li Ma-tou). He was accompanied by Michele Ruggieri (1543-1607; Luo Mingjian), the first European author to be translated into Chinese. ${ }^{5}$ While Ruggieri was aiming at explicitly religious missionary goals, ${ }^{6}$ Ricci was so enthralled by Chinese culture that he expressed a wish to become a Chinese scholar. In 1601 he was allowed to settle permanently in Beijing and, in the garb of a Chinese sage, he was the first European to visit the Forbidden City, where he started work at the imperial institute of astronomy and geography. He did not present himself as a missionary, but rather as someone who had come to learn Chinese wisdom and to share in the values of Chinese culture. The conscious establishment of a mutually equal standing was in harmony with the Confucian tradition of scholarship and conducting learned dialogue. Ricci was also able to offer things the Chinese valued above all else: knowledge, primarily of mathematics, astronomy and geography. ${ }^{7}$ He became renowned as a cartographer when in 1684 he created at least nine world maps based on European data, an act that was far beyond the scope of Chinese knowledge at the time. The Chinese were unaware of lands outside their immediate reach and Ricci's maps significantly improved their geographical knowledge. Ricci also benefitted from a Chinese translation of the ancient Greek mathematical Treatise Euclid's Elements and his ability to calculate solar eclipses with greater accuracy than the Chinese also proved useful. ${ }^{8}$

\footnotetext{
5 The book was Catechism (in Chinese Tianzhu shilu, i.e. "True Account of God"). Ruggieri also wrote the first manuscript of the Portuguese-Chinese dictionary (1583-1588) with Ricci.

6 He had already established St Martin House in Macao (Shengma'erding Jingyuan), where future missionaries learnt Chinese, and in 1582 he was granted permission from the Chinese authorities to establish a permanent mission in Zhaoqing and further develop the Chinese Christian community. On his return to Europe in 1588 he failed in negotiations with the Pope concerning diplomatic representation in China and was sent to Salerno, where he was able to complete his Latin translation of the Four Books (the classic Chinese introduction to Confucius' philosophy), before his death in 1607.

7 Ricci's technical abilities should not be forgotten either, as shown in his appointment as Imperial Clockmaker-a great honour at the imperial court and awarded to very few Europeans.

8 During his years in Beijing, Ricci wrote several books in Chinese: The Secure Treatise on God (1603), The Twenty-five Words (1605), The First Six Books of Euclid (1607), and The Ten Paradoxes (1608).
} 


\section{Propagatio fidei per scientias $^{9}$}

Leibniz followed the intentions of learned missionaries in his understanding of the Christian mission as a cultural and civilisational task, a search for mutual agreement and connections, in favour of a reciprocal understanding. However modern this may appear, the ultimate goal remained that of a mission-conversion to Christianity-and so all knowledge and scholarship, including the application of science, was aimed at that goal: science was intended to serve the glory of God, for the utmost benefit to humanity. Until the last third of the 18th century, nobody in Europe could have claimed superiority in engineering or technology, higher scientific development or economic effectiveness and prosperity: the craft-oriented trade economies of the Indian and Chinese civilisations did not lag behind. The reasons Europe considered itself to stand above the rest of the world were summarised quite realistically, in Leibniz's estimation, by German geographer and historian Anton Friedrich Büsching (1724-1793): Europe is small and therefore has a much firmer structure; it is more powerful than the three other cultures; Europeans have subordinated a larger area of the globe and thanks to their trade, sea and land transport other parts of the world are connected; Europe has been the seat of science and of art for centuries; Europeans are spreading knowledge of the one true God and universal salvation throughout the world (Büsching, 1785).

The Jesuit mission depended largely on the latter and attempted a historic re-enactment of the original Christianisation of the West, this time, however, in the spirit of the Church patres and at the other end of the world. Nevertheless, in order even to be able to deal with the Chinese, foreigners were forced to adapt and comply with their high standards even at the cost of limits to their own self-evaluation. Their motivation was clearly not desire for astronomical knowledge, but to spread the one true faith.

The Jesuits in China soon discovered that they were able to win over politically influential people by emphasising the scientific nature of their work, providing cover for their (ever present) evangelising. Ricci's method of accommodation (Bettray, 1955), first tested in Japan, provided the best results despite the numerous critics dissatisfied with him allegedly adapting Catholic doctrine to the teachings of pagan philosophers. The concerns of Western orthodoxy are understandable, since the image of Christianity Ricci presented to Chinese scholars may have reflected his own religious faith, but a Christian in the 16th or 17th centuries would have been hard put to recognise it. Ricci withheld reports about contemporary wars between Catholics and Protestants and painted a picture of a harmonious religion, common to over 30 Western countries. He claimed that these countries had not entered into war since the introduction of Christianity, knew nothing of violent insurrection, that the rich supported the poor and that its institutions were effective in dealing with social problems. In his collection of essays, Jiren shipian (Li, 2000, p. 545), he spoke of the basic problems of religion, mentioning the shortness of life, the usefulness of considering death, the necessity of fasting, the repayment for good and bad in the afterlife, the foolishness of fortune-telling and the fight against avarice. He discussed any topics that might elicit negative emotions in the Chinese, who were xenophobic and exceptionally proud of their

\footnotetext{
9 Propagation of faith through science.
} 
culture. Chinese Buddhists rejected the concept of a personal god and, in concert with the Confucians, considered laying claim to the truth to be a symptom of a personal deficit. There is no concept of the soul in (Neo-)Confucianism and Christianity was not able to clearly explain the meaning of the term without resorting to unsolvable paralogisms. Attempts to rationally explain Christianity collapsed into banal paradoxes (for Buddhists this was about theodicy, the creation of Lucifer and the angels, justification for the spectacle of the shameful execution of Jesus, Son of God, if it was in his father's power to free humanity of all sin with a single thought, etc.). In this way, Ricci reduced the exegesis of his religion and the society of his origin to their most basic attributes. He consciously avoided discussing the complex Trinitarian doctrine (i.e. the historical focal point of Latin Catholicism), merely mentioning without further comment the incarnation of God into Man and the resurrection (i.e. the central event in Christian Easter), and Christ's physical ascent into Heaven. This abridgement of the faith, the false picture of the history and contemporary era of European culture, the concealed evangelising mission, together with the emphasis on knowledge, science and art, eventually lead to the creation of the "Myth of Europe" (Li, 2000, 249ff.), or the exploitation of China's lack of knowledge of distant continents, but at the same time it gave Ricci access to influential figures in the Chinese Empire.

Through his activities he simultaneously prepared the ground for the subsequent generation of Jesuit missionaries, who reached their peak during the Dinq dynasty and in the era of the emperors Shùnzhì (1644-1661) and Kāngxī (1662-1722). Under them the work of the missionaries had such a good reputation that they were free to practice without hindrance in the city and province of Beijing. For the first time in history, missionaries were allowed to make direct personal contact with the Chinese emperor. The Jesuit Johann Adam Schall von Bell (T'ang Jo-wang), of German ancestry, had already made a name for himself under the last emperor of the Ming dynasty with his knowledge of astronomy, and much more appealing skills of designing and casting cannon. As noted by J. Needham, the Jesuits frequently dazzled the imperial court with the precision and reliability of their methods for observing celestial events, because in the Chinese worldview this knowledge was crucial to maintaining the balance between worldly and cosmic occurrences. At the same time they kept a number of new discoveries secret from the Chinese, even providing them with false explanations and hypotheses. A typical example was their support for geocentric Aristotelian-Ptolemaic theory and concealment or even denial of Copernicus' heliocentrism, which were much more in line with Chinese teachings on the movement of heavenly bodies in infinite space (Needham, 1984). After the new dynasty took the throne in 1645, an accurate calendar was required to minimise the inaccuracy and irregularity of events and things generally interpreted as bad omens. They were also looking for experts in military technology. Adam Schall was eventually chosen and charged with leading the Astronomical Bureau $^{10}$ (Ch'in t'ien chien), thereby becoming a high state official and member of the allpowerful government bureaucracy.

\footnotetext{
${ }^{10}$ The imperial astronomical institute had been established in the 13th century under the Yuan dynasty. It was originally staffed by Arab (Muslim) astronomers who had only one task, albeit a crucial one- to establish the Chinese calendar. After 1600, the directors of this institution had been Arab Muslims, and this only changed with the arrival of the original Jesuit mission.
} 
Any association with state power, however, brings risks that become evident whenever the power structure is replaced. The Jesuit mission was put in danger on Schall's death in 1666, when emperor Kāngxî̀'s regents made every attempt to reduce its influence, including by persecuting missionaries and punishing their Chinese collaborators. It was four years before Kāngxī finally secured full power and the regular Belgian friar Ferdinand Verbiest (Nan Huai-jen) was named Schall's successor and director of the Imperial Bureau of Astronomy. Other Jesuits arrived at court with him (another Belgian - Antoine Thomas, and Claudio Filippo Grimaldi, Antoine Verjus, Joachim Bouvet, Jean-François Gerbillon and others who later influenced Leibniz), and also advised the emperor in diplomatic, foreign policy and military issues. As translators and advisors, they were involved in concluding the first Sino-Russian treaty, ${ }^{11}$ as military strategists in the battles at Ulan Butung (1690) and at Jao Modo (the battle at Zuunmod, 1696) ${ }^{12}$ and as publishers in issuing the great atlas of the Chinese Empire. ${ }^{13}$ The power of the Jesuit mission grew and, apart from running the astronomical and mathematical bureau, the missionaries conducted anatomical research. Ricci's vision of "Christianisation from above" was being fulfilled, moving from high society with its interest in science and art to the lower levels of Chinese commoners through their interest in Western tools and technology. Science and engineering therefore directly served the religious goal the Jesuit mission had kept secret. Ricci himself wrote: "If they [the Chinese] wish to learn our sciences, not only shall they gain great expertise, but we shall thereby also easily introduce them to our holy religion" (Li, 2000, p. 31, note 21). However, even this teleological approach of the missionaries eventually reached its limits. Shortly after the death of emperor Kāngxī, Jesuit missionaries high up in the Chinese hierarchy lost their protected status, and his successor Yongzheng (1678-1735) stripped the mission of its privileges and expelled all the missionaries, sending them back to Macao.

\section{The intellectual tradition of the Enlightenment}

Leibniz was no great admirer of the Enlightenment as an intellectual movement, since his personal growth took place at a time when Enlightenment rationalism was still being formed. His positions, intentions and expectations regarding education were, however, essentially identical to the worldview expressed by French and German Enlightenment intellectuals. Leibniz's philosophical and-when understood broadly—cultural, political and educational work was significantly influenced by strains of thought found in the critical (transcendental) idealism of the Enlightenment rationalists. The European Enlightenment stood on two

\footnotetext{
${ }_{11}$ The Treaty of Nerchinsk of 27 August 1689 on borders and trade which ended the thirty-year SinoRussian war in the Baikal region.

${ }^{12}$ In the primary battles of the Quinq dynasty against the Zunghar Khanate (1690-1758, allegedly involving genocide) the missionaries taught emperor Kāngxī European battle strategy and the use of cannons and muskets; the Chinese army carried 235 cannon across the Gobi desert on camels and destroyed the army of the Khanate.

${ }_{13}$ The so-called Jesuit atlas (Huangyu Quanlan Tu; and sometimes the atlas of Emperor Kāngxī), compare Fuchs, W., Der Jesuiten Atlas der K'anghsi-Zeit, Beijing 1943 (Wiesbaden, 1988); Perdue C. P. (2005). China marches west: The Qing Conquest of Central Eurasia. Cambridge - London: Harvard University Press.
} 
foundational traditions, formed within pre-Leibniz philosophy (by Descartes and Hume) and following up on Hume with Kantian transcendentalism. Leibniz's well-known principle, given in many textbooks without being adequately understood, states: nihil sine ratione [nothing is without reason]. If this were a requirement made of humanity, it would be impossible to achieve. If it were a rule or guideline for his philosophy, it would be difficult to understand which principle it represents or which concept of reason it establishes.

Nihil sine ratione is an elegant and optimistically formulated principle of the new age that reason should be applied to all situations. Leibniz is talking about the application of reason leading to the absolute rejection of situations in which unreason rules over us. However, the word application refers to method, but Leibniz does not explain the method or justification for applying reason. This is a serious problem because it is precisely the method that indicates the rationality of applying a particular solution to a situation. In Leibniz's time, method referred to a natural science method (i.e. including natural philosophy). If , for instance, we remain firmly in the realms of physics or mathematics, we will not face methodological problems, something Leibniz was very well aware of. However, the principle of rationality must also hold true in metaphysics, ontology, theology or morality, that is, in the general spheres of the normative regulation of human behaviour and action, where a methodological basis may be found in transcendental criticism, but not in the methods of natural science. A perfectionist, Leibniz tried repeatedly (the literature mentions fifty reformulations; Nicolás, 2002, p. 897) over the course of his life to clarify precisely the intention behind the principle nihil sine ratione. One thing is clear: he accommodated the intellectual atmosphere of Europe at the start of its Enlightenment transformation and so, however idiomatic, peculiar or novel his positions were, they were responses to the context of the time and accepted it. It is just as credible that his insatiable life-long interest in the meaning and application of rational decision-making in the advanced culture of the Chinese Empire, untouched by European influences, also followed his own goals, leading him to being open to other cultures in a way that would be exceptional even today.

The exclusivity of reason reflected pre-Enlightenment rationalist philosophical tendencies, consisting of three basic aspects: the role of method in guiding reason in learning; the relationship between reason (pure rationality) and practice; and the establishment of a new science defined through reason and its importance in normative, especially ethical systems (Nicolás, 2002, pp. 894-896). Leibniz's concept of philosophical rationalism contained all three, with only minor modifications, and their real impact on the decline of the enlightenment tradition of critical reason only became clear in the period after Kant's Critique of Practical Reason. Leibniz's interpretation of the principle of the exclusivity of reason was ignorant of any of the postulates of Kant's criticism, and this meant he could make reason the central point in philosophy, around which he could then systematise a significant portion of his own philosophy (metaphysics, theology and ethics). This unintentionally, but unavoidably, led to the creation of what was essentially one of the first enlightenment models of rationalist fundamentalism. Consequently it led inevitably to the failure to complete enlightenment thinking and later to the abandonment of enlightenment demands, as well as to a crisis of the idea of reason. It contained (still in accordance with nihil sine ratione) a logical and methodological level related to metaphysics and deductive reasoning, a level of ontological realism with an objective relation to theology 
as well as a methodological relation to teleological approaches and a level of practical ethics related to the sphere of morality and conforming to the principle of methodological coherence.

Leibniz's attempts to create an ideal system of intellectual cooperation between the West and China were framed within the overall context of the era and therefore resulted in the tendency to accept a unified (modern) enlightenment concept of reason. Its greatest shortcomings (reason being reduced to logic or the methodology of knowledge and a rejection of experience; internal inconsistency and the lack of systematisation stemming from the necessary distinction between rational theory and practice) became evident perhaps half a century after Leibniz's death. To a certain degree, Leibniz did provide a comprehensive theory of reason, knowledge and cognition, while going beyond the contemporary mechanical philosophy of science by including additional issues of human freedom, the goals and meaning behind knowledge, life and biological vitalism in general, and the properties of observed objects and their developmental dynamism. an extract of which was also the core of his question concerning Chinese scholarship.

\section{Leibniz, precursor to the theory of recognition}

A virtuous life is founded in knowledge. While Leibniz acknowledged the validity of this overt intellectualism, whose end could be nothing less than the equivalence of personal, that is educational, perfection with moral perfection (together with the ability to counteract scepticism and moral relativism), he was loath to connect his system of philosophy to the single principle of pure reason. Conflicts of interest between people call for a practical approach with good (as good as possible) theoretical underpinnings. Leibniz thought the principle of perfection (principium perfectionis) was directed at united and self-unified thought (thought is a model of the integration of plurality within the monad) and therefore leads to a loss of unity within the self and a division into the areas of possible worldly perfection (ontology, morality and logic). This was how Leibniz described the practical (moral) character of rationality: the laws of reason apply equally to the ontological sphere (the world) and the moral sphere (practical human behaviour); they govern both God and Man.

A person in action must calculate, assess both the potential and the risk, success and failure, and the long-term or short-term gain. These are dependent on the person's knowledge: they are not political calculations, but rather acts of thought regulated by the laws and structures of rational knowledge. According to Leibniz the starting point for regulated thought is justice. In order for this ethical and political category to function, it has to be linked to fundamental operational criteria, which Leibniz termed the principe de la place d'autruy ${ }^{14}$ (to put yourself in the position of the other, Reiner, 1983, p. 274). That is to say, before commencing any activity a person should mentally adopt the position of those potentially influenced by their actions; this eccentric positioning allows one to perceive

\footnotetext{
${ }^{14}$ Comp. Leibniz, G. W., Nouveaux Essais sur l'entendement humain [New essays on human understanding], chap. 2, §4 ("La place d'autruy est le vray point de perspective en politique aussi bien qu'en morale.”)
} 
the interests, consequences, wishes and needs of others, which might otherwise remain unknown. The principle of assuming the position of the other does not mean that Leibniz's thought on cross-cultural contact and worldwide intellectual unity was defined by inter- or trans-subjectivity, instead it points more to a distancing from Eurocentric scepticism towards the scientific and cultural abilities of other civilisations. The rejection of this scepticism is a possible form of recognition of the other as an equal, and a rejection of ethnic, racial and religious superiority.

Leibniz's entire system of scientific and theoretical deliberations had a practical justification. Its purpose was ultimately to provide humanity with as many means as possible to effectively influence natural processes and to create social institutions and structures which would as a whole serve to help people in their pursuit of happiness. This purpose moulds scientific activity, especially in the expansion and enrichment of thought in crosscultural exchange; for Leibniz science and logic gain meaning through practice, which can once more only be rational in structure because it is governed by logic in the sense of nihil sine ratione. Leibniz included this bilateralism as a methodological requirement in his concept of two-way scientific cooperation between the European and Chinese civilisations.

Undeniably, the Jesuit mission was the most tightly-knit and well-educated group of people in China doing systematic work on human knowledge at the educational, moral and administrative-political level in the Eastern empire. Leibniz came into contact with the mission in 1689 in Rome, where he met Claudio Filippo Grimaldi (called Mi Mingwo), a high ranking member of the mission under the rule of Emperor Kāngxī, with whom he remained in written contact for the remainder of his life. The first three records of the meeting with Grimaldi show us the specific nature of Leibniz's approach to learning about China (Leibniz, 2006, pp. 2, 6, 10, 16). According to Leibniz the ability to create universal ideas comes naturally to humans, and so one would expect the intellectual basis of a unified worldview in which justice, well-being, knowledge and the comprehension of God are crucial to have emerged in ancient Greek philosophy just as it had in older Chinese philosophy. The requirement for a universal knowledge based on the premise of a universal language of science is perspectivist, as it is aimed at improving the living conditions of humans and promoting their liberty. Human knowledge is limited and discursive, and for Leibniz this means we can approach knowledge, try variations of it, formulate hypotheses and test assumptions. Generally speaking, from the human perspective (rather than from a divine one) universal knowledge is simply the result of development unfettered by any barriers to the freedom of inquiry. The relationship towards knowledge in Chinese culture reflects this perspectivism: Chinese knowledge as a whole represented an as yet unexplored and unmeasured value. All that could be said at that point was that it had just as much import in regard to the concept of universal knowledge as did European science and culture, and in places even more. After their first conversation, mainly covering the language and writing of China and Russia, the kinship of nations within the Siberian and Mongolian space as well as issues of geography, Grimaldi stated that his knowledge of the issues at hand was insufficient and offered to provide Leibniz with further answers to his questions after consulting other Jesuit missionaries in Beijing. Leibniz was clearly delighted with Grimaldi's offer and 
made full use of it: he immediately prepared a list of 30 questions covering a broad area of interests, in an attempt to capture every issue of any relevance to Europe. ${ }^{15}$

Leibniz's list provides no clear idea of the kind of knowledge Leibniz and his contemporaries were actually aiming at: despite the varied content of the questions, their general thrust seems to be towards applied science, in particular technologies for the production of consumer goods. Based on his knowledge of the literature of the time, Leibniz was partially justified in thinking that Europe could learn a number of production processes from China that would lead to improvements in the quality of everyday life as well as greater safety and better defence. In subsequent letters he mentioned that he was considering a bilateral relationship, ${ }^{16}$ the mutual exchange or trade of knowledge and skills: On 2 December 1697 he wrote to A. Verjus

...I am of the opinion that the Chinese mission is the most important trade enterprise of our times $[\ldots]$ since it is a trade in knowledge, capable of at one leap bringing in the fruits of their labour of centuries, and on the other hand providing the Chinese with the bounty of ours. In this way both sides can double our real wealth, this is much larger than one might have been led to believe (Leibniz, 2006, p. 127).

Leibniz's enthusiasm for China's role in developing human harmony worldwide was reflected in the preface to Novissima Sinica, historiam nostri temporis illustratura ([Latest from China] Leibniz, 1697), which represents the beginning of modern discussions of Chinese culture in European philosophy (Li \& Poser, 2000). It differs from previous interpretations by one crucial characteristic: Leibniz accepted the premise that human culture was truly universal, foundational to the central ideal of "one world" common to all humanity and all (developed) cultures, and that its meaning could not be ignored and remained relative at all times, that is, becomes clear only in relation to others. He wrote,

The unique imprint of fate has, I suppose, led to the highest cultures and the highest technological civilizations of humanity to gather in the two furthermost corners of our continent, i.e. in Europe and in China, which has graced that opposite side of the world as something of a Europe in the East. And so perhaps does Providence have as its goal that-

\footnotetext{
${ }^{15}$ The first question was whether the Chinese were capable of making better fireworks than Europeans were, the eighth asked how the Chinese gathered silk cocoons twice a year, the twelfth concerned Japanese sheet metal production, the seventeenth was on the production of lye-resistant dyes, the twenty-fourth on the existence of any machines that would be worth the Europeans copying, the twentyninth on their military technology, and the thirtieth on their mining of ore and minerals and their production of salt. Only a few of the questions were concerned with philosophy, natural and intellectual history, while one was on linguistics (clavis sinica [Key to the Chinese Language]) and none were concerned with religion. Over the life of the "oldest mission", the Jesuits in China were unable to find answers to all the questions on Leibniz's list. Comp. Leibniz,2006, pp. 12-14.

${ }^{16}$ Leibniz did not define precisely what he meant by civilisational equivalence, nor the basis for a cross-cultural comparison which would compare that equivalence, neither did he consider the intercultural criteria clearly necessary as a precursor to equivalence as a construction of (minimal) civilisational similarities. He intuitively assumed the equal value of China and the Christian West as a condition for mutually beneficial (trade) relations, but long-term equality and mutual recognition cannot function under such a vague basis.
} 
while the most civilised (and most distant) nations clasp each other's hands-this will lead all that lies between them gradually towards the rational life. (Leibniz, 1697, p. 2$)^{17}$

When Leibniz talks of "our continent" he is referring to Eurasia, whose cultural poles are connected by Russia:

It is no accident that the Russians, whose vast empire connects China with Europe [...] are, by the very efforts of their ruler, as well as the recommendations of the patriarchs who support him, hurrying to rapidly catch up with our innovations (Leibniz, 1697, p. 2).

In the ensuing twenty-three paragraphs, Leibniz summarised his findings on China so far ("In the abilities necessary for everyday life and in the experimental inquiry of Nature we are equals, with each side possessing such skills as could be usefully exchanged with the other"); elevated European metaphysics and theoretical knowledge and described Chinese behavioural social norms as far surpassing Europe "...in the area of practical philosophy, [...] in the ethical and political sciences aimed at everyday life and the daily habits of people themselves" and as avoiding causing others distress through vulgar or aggressive actions; noted the effectiveness of their state administration and bureaucracy, which had reached a higher level than elsewhere and was capable of organising and coordinating the behaviour of millions of people, and consequently it "...managed in its vast social efforts perhaps more than all the founders of Christian orders in their tight circles altogether." However, he was quick to note that to a European not brought up within a single system of rules and principles, the carefully worked out codes of civility and decorum may "... seem to contain somewhat of a self-imposed servility." 18

He discussed the role of emperor generally, giving high praise to the Chinese emperor of the time, Kāngxī, emphasising the unusual role given to education, culture and knowledge by emperors that stemmed from the premise that as the Sons of Heaven and first among their people they must also strive to be first in upbringing and education. For this reason they welcomed the wisdom acquired through their contact with the Europeans: Leibniz thought Emperor Kāngxī "an unprecedentedly excellent ruler" who saw "even further as an individual than his highest officials and the basis for his excellent wisdom was his ability to join the European with the Chinese". ${ }^{19}$ Leibniz then discussed mathematics in detail, the "golden apple" that could be brought to the Chinese and the history of the Jesuit mission. Despite allowing many a simplification and idealisation into the preface to Novissima Sinica, Leibniz still managed to point out that besides Western European culture there was also an Eastern, or East-Asian, culture whose common basis was China and that these two

\footnotetext{
${ }^{17}$ The translation used here is the 2 nd edition of the Latest News of China from 1699. Comp. Das Neuste von China. Zur Erhellung der Geschichte unserer Zeit, in Studien von Zeitfragen, Jg. 36, InternetAusgabe 2002. Retrieved from http://www.mnemeion.studien-von-zeitfragen.net/Leibniz/ NOVISS_1/noviss_1.HTM. 13/02/2020.

${ }_{18}$ All citations are from Leibniz (1697).

${ }^{19}$ In the original tantaeque prudentiae causam hanc esse existimo, quod Sinensibus Europaea coniunxit; Leibniz's thinking was therefore somewhat essentialist, as in "Europeanness" and "Chineseness", and he did not stop to consider how these terms should be defined or what they identified.
} 
were of the greatest worldwide importance. After Leibniz, this finding could be denied or suppressed, but it continued to be true from that time onwards.

Leibniz's description of China's political system, philosophy, literature and culture was surpassed multiple times in the 18th century, as were his solutions to Chinese mathematical formulas. ${ }^{20}$ His original intentions vis-à-vis the cultural and scientific exchange were not entirely honest: Leibniz wanted to reform classical Chinese philosophical thought, perhaps in accordance with the "Platonic Confucianism" he had adopted (Li, 2017, p. 240), an analogy perhaps to his efforts to "reform" Western Aristotelianism. He only gave up on this attempt as his lack of knowledge of Chinese prevented him from gaining a more complex picture of Chinese thought. Apart from that he wondered whether or not it was correct to divulge to such a powerful nation, who were not Christians and not likely to be any time soon, "all our mathematical and military secrets" (Jannidis, Lauer, \& Martínez, 2003, p. 655). This concern regarding China can perhaps be seen as evidence of his consequentialism. After all, his relatively unusual approach to information prevented him from publishing his own manuscripts with his plan for Scientia generalis [Universal science], which he only referred to in private. In all respects Leibniz was, however, a Christian, a supporter of Lutheran Protestantism, who had entered into an unusual coalition with a small group of Jesuit missionaries and it was from that position that he took part in the attempt to prepare China, one of the oldest human civilisations in history, to accept Christianity through the medium of European philosophy and science.

Leibniz never completed his translatio sapientiae between Europe and China, despite several attempts, and his last manuscript on the "natural theology" of the Chinese remained unfinished (Leibniz, 2002). A remarkable comment was found in Novissima Sinica:

The state of affairs here seems to me to be truly such, that with the unbridled increase in moral corruption one could almost consider it necessary for Chinese missionaries to be sent here, in order to teach us the purpose and proper use of natural theology, just as we are sending similar missions to them, to educate them in the name of revealed religion (Leibniz, 1697).

This popular thesis, sometimes understood as a call to abandon the European tradition and replace Christianity, is a misunderstanding of what Leibniz considered to be "natural theology" and the reason he thought it existed in China. Discourse on the Natural Theology of the Chinese (DNT) was intended to explain just that, being a highly detailed interpretation of Chinese thought derived from the cultural repository of the entire Occident, as represented by the polyhistorian Leibniz. None of his discourses clarify the metaphysical basis of his reasoning on the educational unity of civilisations: the assumption that there is a single truth at the foundation of all cultures, and that they can therefore be joined together and unified. At the same time this assumption states that the project of universal unity and harmony must

\footnotetext{
${ }^{20}$ The most popular reinterpretations include the arithmetic by Franz Anton Knittel (1721-1792), the formally-logical by Johann Heinrich Hasenbalg (1696-1747) and the algebraic by Johann Thomas Haupt (before 1785). These were revisions of interpretations of the mathematical works of the first Chinese Emperor Fo-si Ye-kim published in Rostock. Haupt reviewed it, using a so-called cubocubus to explain it. Comp. for example Hopkins, B. C. (2011). The Origin of the Logic of Symbolic Mathematics: Edmund Husserl and Jacob Klein, Bloomington: Indiana University Press.
} 
either impose one truth on everyone, or ultimately fail. Anyone living in Europe after the Thirty Years War would have had a better understanding of this framework than was shown by Leibniz. Finally and not merely for this reason, but also because of the many factual errors in Leibniz's discourse, the DNT cannot be discussed within the context of Chinese philosophy alone. ${ }^{21}$

As with many writings over the history of philosophy, the DNT was also a somewhat incidental work in which Leibniz was responding to a plea by Nicolas-Françoise Rémond (1638-1725), whom he had been corresponding with since 1713. The plea concerned Leibniz's understanding of the conflict surrounding the method of missionary work in China and the discussion of Chinese Confucianism which was taking place throughout the Jesuit mission, but significantly influenced by the Vatican on the one hand and the basic antagonism between the Dominican and Jesuit missions on the other. Leibniz wrote of "natural theology" in order to establish a basis on which the two missionary positions could be compared and that would include his own view of Confucianism. The term "natural theology" is, however, like most of the terms used in Europe (and often even today) in relation to Chinese culture, a Eurocentric notion that is incapable of capturing Chinese forms and classifications of knowledge. No hermeneutic thinker with insufficient linguistic means at his disposal can be expected to produce more than a reformulation of other, foreign thought according to its own laws of reason. Leibniz's lack of knowledge of the original Chinese texts left him with little choice but to focus on a critical evaluation of the so-called reductionist interpretation of Confucianism as presented by French Jesuits Langobardi and Antoine St. Marie, instead of evaluating whether or not his own understanding of Chinese thought was accurate and relevant. The DNT is therefore not a ground-breaking nor a foundational work of comparative or polylogical philosophy or the philosophy of religion. The value of that part of Leibniz's work on China lies in the fact that it comes at the end of a long chain of variously motivated research into Chinese philosophy and literature, including centuries of disagreements among Chinese scholars, interpretations of their concepts by nonChinese scholars, especially Portuguese and French Jesuit missionaries and the controversy within their Christian readings of Chinese philosophy. The DNT simplistically portrays the controversy as a struggle between two approaches and, after a ground-breaking analysis of the textual sources, leans in favour of Confucianism. In this manner Leibniz began preparing the ground for further developments in the interpretation of Chinese philosophy, specifically the shift away from interpretation and towards a living and comprehending cross-cultural dialogue which the two cultures await to this day.

\footnotetext{
${ }^{21}$ The same is true of another work that has "philosophy" in its title, Philosophia Sinica [Chinese Philosophy] by the Belgian Jesuit François Noël (1651-1729), published in 1711 in Prague, and which Leibniz knew of (it was Des Bosses who notified Leibniz of Noël's stay in Prague in October 1710, comp. Leibniz, 2017, pp. 186-187). According to some scholars, for example Henrik Jäger, there are significant parallels between the two works (comp. Li, 2017, pp. 129-146, esp. p. 143). This, however, fails to explain why Noël's book, which the Church of course immediately lay claim to, soon became unavailable to contemporary scientists. One expert on Chinese political philosophy, G. B. Bilfinger, expressed his surprise at the sudden rarity of the book, forcing him to use older and less known texts (Nescio, quae caussa illos faciat rarissimos? [I don't know, which cause them to make the rarest], Bilfinger, 1724, § 19, esp. 17).
} 
Under these conditions, the $D N T$ could have scarcely avoided being an apologia, and this also explains why Leibniz neglected to thoroughly apply his own philosophy, as that step was rendered largely superfluous. He gave his opinion on the dispute about whether Chinese learning, which relied on so-called Neo-Confucianism, was atheistic as claimed by Langobardi, or whether the tradition established by Ricci's accommodation method held true: that Chinese writing, characters, teaching, their concept of history and chronology in general were in their own way a "reconfiguration" of biblical truths, just as the Old Testament contains certain fragments of the New Testament. This idea was further developed by the French Jesuit Joachim Bouvet in his "figurative system", first described in a letter to Leibniz on 15 September 1704. Leibniz held the position that Confucianism was not a religion, leaving China an open field for the spread of Christianity. To simplify, the practical issue was whether certain Chinese words could be used as analogies of the Latin concept of God, which would mean that the Chinese had some knowledge of God in even their earliest philosophy, and whether certain rites, habits and customs, such as ancestor worship or the cult of Confucius, were of a civic or religious nature. At the same time they all, including Leibniz, rejected Neo-Confucianism, and blamed its interpretation of canonical books as a failure of explanation which instead obscured and prevented the Chinese themselves from understanding their true and original meaning.

Leibniz's sources for his discussion with Langobardi and St. Marie were the French printed editions of their polemics. These were not originally intended for publication, but served as resources for making arguments in debates and included extensive Chinese citations and original Chinese diagrams meant to facilitate a deliberate and balanced decision on the future of the mission. However, first Spanish and later other European publishers scrubbed these sections from the text, added a number of notes and made deletions and modifications. Leibniz was therefore reading a fluid, coherent and distinctly polemical text, which greatly differed from the colourful and pluralistic discussion in the original. ${ }^{22}$ It is unclear whether this was the reason Leibniz defended Neo-Confucian texts that he considered "old" and therefore appropriate (but it may have just been a simple case of mistaken sources). He rejected the notion that Confucian philosophy was naturalistic and pantheistic and indicated the possibility of synthesising the basic principles of Chinese and Christian philosophy, based on a discussion of three great principles in Confucianism ( $L i$, the original principle of the universe; $K i$, the principle of original matter and material creation; and the principle of Shang ti, the Lord of Heaven, which comes close to the Christian concept of God). He thought this would be the methodological basis for a new global cooperation between all cultures, leading to the flourishing of a shared science for the benefit of all humanity.

\section{Epilogue}

Leibniz's notion of a humankind engaged in cosmopolitan cooperation, creating and sharing knowledge cultures and helping improve the lives of everyone attracted no followers during

${ }^{22}$ Newer revisions based on the Portuguese and Latin originals are unavailable to this day. 
his lifetime, nor after his death. His letters and a number of scholarly works remained sealed in his archive in Hannover, unavailable for further study and after several decades were largely forgotten. The German philosopher Christian Wolff, who made an effort to continue with Leibniz's project, mentioned the DNT in his Oratio de Sinarum philosophia practica [Discourse on the Practical Philosophy of the Chinese], the inaugural speech he gave as university prorector in Halle in 1721 (Wolff, 1988). In it he claimed that Chinese philosophy did not prescribe any human behaviour or morals that were not in accord with the nature of the human spirit or that went against Nature. Wolff's speech led to accusations of atheism in religious circles of the time, his expulsion from the university and exile from Prussia. King Friedrich Wilhelm I exclaimed in alarm "I had no idea Wolff was so godless" and gave him 48 hours to emigrate: he was declared godless merely for recommending the study of the scholarship of "those heathen Chinese". His Oratio is undeniably an important moment in the Enlightenment, although it is difficult to state its relevance to the history of cross-cultural philosophical interpretation.

The Jesuit mission in China was in decline, even under emperor Kāngxī, for a number of reasons. In the Church and above all within the Dominican and Franciscan orders, there was growing resistance to Ricci and Schall's missionary policy of accommodation, toleration of Confucian rites and veneration of ancestors and the emperor. Newly arriving missionaries acted much more aggressively, openly calling for the baptism of the emperor and the Christianisation of China. These expressions of absolute ignorance of the culture the missionaries had been admitted into as guests played an important role in the subsequent expulsion of Christian missionaries from the country and the prohibition of all forms of Christianity. After the papal brief on the suppression of the Jesuit order arrived in Beijing in 1774 , there were also a number of heated public exchanges between delegates and individuals from various Christian orders, which greatly dissuaded the Chinese onlookers from any further contact owing to the lack of respect for proper behavioural protocol. For the educated Chinese classes this meant that Christianity had fallen to the level of the "vulgar Taoist" and "vulgar Buddhist" sects (Franke, 1962, p. 51). There was no longer a place for them in China.

The literature (Franke, 1962, p. 51an.) often mentions that the decision of the Roman Curia on the dispute about the recognition of rites, the behaviour and actions of certain papal delegates at the court (esp. Cardinal de Tournon) and the fight for control over the Christian missions in various cultures was a precursor to the development of Sino-Western relations in the 18th and 19th centuries, then characterised by the interests of imperial power, colonialism and the racist associations of nationalism. Such direct causation is clearly unverifiable, but it is clear that Rome's stance on the matter (as well as that of certain Protestant denominations and circles, e.g. the Jansenists) may have led to pathways for approaching foreign cultures. This pathway was the tao of European culture, with its hubris and divided thinking, disunity of spirit, selective memory, insatiability and thirst for power. A typical example of this tao was the approach adopted by the so-called Göttingen school of history (esp. Schlözer, Meiners, Gatterer), which influenced Western thought, especially in 1770 to 1840 when an uncertain and weakened China chose the policy of isolationism. To scholars following this school, China remained a backward and barbarian culture, and they were the first to label the Chinese Halbmenschen, undeveloped, uneducated, half-enlightened subhumans. The main representative of this school, A. L. Schlözer, summarised the need for European rule thus, 
"Europe is equipped with many tools: the compass, gunpowder, paper and print, eye-glasses, clocks and the postage system. Using these inventions we have discovered three new worlds and subordinated them to our will, plundered, cultivated or ravaged them" (Schlözer, 1785, p. 104).

The alternative approach noted and described by Leibniz is, however, still possible. Perhaps it will remain the proverbial message in a bottle, hurled into the sea and waiting for the right person to fish it out, comprehend it and realise its potential. Whether this will take place in the current era of America first is questionable at best.

\section{References}

Bettray, J. (1955). Die Akkomodationsmethode des P. Matteo Ricci S. J. in China. Analecta Gregoriana, Band 76. Roma: Gregorian \& Biblical Press.

Bilfinger, G. B. (1724). Specimen doctrinae veterum Sinarum moralis et politicae; tanquam exemplum philosophiae gentium ad rempublicam applicatae: excerptum libellis sinicae genti classicis, Confucii sive dicta, sive facta complexis. Accedit de Litteratura Sinensi dissertatio Extemporalis [Characterization of the ethical and political doctrine of the ancient Chinese]. Frankfurt a. M.: Andreae Verlag. (Reprint published 1999, Hildesheim Olms Verlag. Also reprinted in Wolff, Ch. (1962). Gesammelte Werke 3, 55. Hildesheim: Olms Verlag.)

Büsching, A. F. (1785). Auszug aus seiner Erdbeschreibung. Erster Theil, welcher Europa und den nordlichen Theil von Asia enthält [Sample from his description of Earth: Episode One]. Hamburg: Johann Carl Bohn.

Franke, W. (1962). China und das Abendland. [China and the Occident]. Göttingen: Vandenhoeck\& Ruprecht

Jannidis, F., Lauer, G., \& Martínez, M. (2003). Regeln der Bedeutung: zur Theorie der Bedeutung literarischer Texte [Rules of meaning]. Berlin - New York: Walter de Gruyter.

Kircher, A. (1667). Athanasii Kircheri E Soc. Jesu China Monumentis ... Illustrata. Amstelodami: Janssonius a Waesberge; Weyerstraet.

Leibniz, G. W. (1697). Novissima Sinica, historiam nostri temporis illustratura [Latest from China]. Hannover: Nikolaus Foerster.

Leibniz, G. W. (1997). Discourse on the natural theology of the Chinese. (Trans. with an Introd., Notes and Comm. by Rosemont, H. Jr. \& Cook, D. J.). Honolulu: The University Press of Hawaii.

Leibniz, G. W. (2002). Discours sur la Theologie Naturelle des Chinois, mit einem Anhang von Niccolò Longobardis Traité sur quelques points de la religion des Chinois, Antoine de Sainte Maries Traité sur quelques points importans de la Mission de la Chine, Nicolas Malebranches Entretien d'un Philosophe Chrétien et d'un Philosophe Chinois sur l'Existence et la Nature de Dieu, jeweils mit Leibnizens Marginalien [Discourse on the natural theology of the Chinese]. (Eds. and Notes Li W. \& Poser H.). Frankfurt a. M.: Vittorio Klostermann.

Leibniz, G. W. (2006). Der Briefwechsel mit den Jesuiten in China (1689-1714). [Letters to Jesuits in China]. (Widmaier R. Eds., Introd., Babin M. L., Trans. French - Latin - German). Philosophy Library 548. Hamburg: Felix Meiner Press.

Leibniz, G. W. (2017). Briefe über China (1694-1716). Die Korrespondenz mit Barthelemy des Bosses S. J. und anderen Mitgliedern des Ordens. [Letters about China 1694-1716]. (Widmaier, R. \& Babin, M.L., Eds. Babin, M.L., Trans. French - Latin - German). Hamburg: Felix Meiner Press.

Li, W. (2000). Die Christliche China-Mission im 17. Jahrhundert. Verständnis, Unverständnis, Missverständnis. [A Christian mission in China in the 17th century]. Studia Leibnitiana, Suplementa (32). Stuttgart: Franz Steiner Press. 
Li, W., \& Poser, H. (Eds.) (2000). Das neuste über China [Latest from China]. G. W. Leibnizens Novissima Sinica 1697. Studia Leibnitiana, Suplementa (33). Stuttgart: Franz Steiner Press.

Li, W. (Ed.) (2017). Leibniz and the European encounter with China: 300 years of Discours sur la théologie naturelle des Chinois. Stuttgart: Steiner Press.

Merkel, F. R. (1952). Leibniz und China. Berlin - New York: Walter de Gruyter.

Needham, J. (1984). Wissenschaft und Zivilisation in China, Band I. [Science and civilization in China. Vol. I] (Ronan C. A., Ed.). Frankfurt a. M.: Suhrkamp Press.

Nicolás, J. A. (2002). Die Krise der Aufklärung: Die Leibniz'sche Alternative. [The Enlightenment crisis. The alternative of Leibniz]. In Poser H. (Ed.). Nihil sine ratione: Mensch, Natur und Technik im Wirken von G.W. Leibniz [Man, nature and technology in the work of G. W. Leibniz]. Berlin: G.-W. Leibniz-Gesellschaft Press.

Noël, F. (1711). Sinensis Imperii libri classici sex: nimirum Adultorum Schola, Immutabile Medium, Liber Sententiarum, Memcius, Filialis Observantia, Parvulorum Schola, e Sinico idiomate in latinum traducti a P. Francisco Noel Societatis Jesu missionario [Six classics of Chinese Empire]. Prague: Kamenicky Press.

Reiner, H. (1983). Duty and inclination: The fundamentals of morality discussed and redefined with special regard to Kant and Schiller. The Hague: Martinus Nijhoff Publishers.

Schlözer, A. L. (1785). WeltGeschichte nach ihren HauptTheilen im Auszug und Zusammenhange. $B d$. 1. [The connections between the major parts of world history. Vol. 1]. Göttingen: Widow Vandenhoeck 's Publishing House.

Widmaier, R (2006). Introduction. In Leibniz, G. W. (2006). Der Briefwechsel mit den Jesuiten in China (1689-1714). [Letters to Jesuits in China (1689-1714)]. (Widmaier R. \& Babin, M. L., Eds., Babin, M. L., Trans. ). Philosophische Bibliothek, 548. Hamburg: Felix Meiner Press.

Wolff, C. (1988). Oratio de Sinarum philosophia practica [Discourse on the practical philosophy of the Chinese.] (Albrecht. M., Preface, Ed. and Trans.). Hamburg: Felix Meiner Press.

Institute of Philosophy

Slovak Academy of Sciences

Klemensova 2522/19

81109 Bratislava

Slovakia

Email: filohory@savba.sk

ORCID: 0000-0002-6610-246X 